\title{
Impact of Pre and Postnatal Protein Energy Deprivation on Structure of the Trigeminal Ganglion of Weanling Rats
}

\author{
L.S. Simões, S.C. Boldrini, C.B. Binotti, T.S.O. Capote and E.A. Liberti* \\ VQM Autonomic Nervous System Laboratory, Anatomy Department, University of Sao Paulo, Brazil
}

\begin{abstract}
The effects of protein energy deprivation (PED) on trigeminal ganglion sectional area, neuronal density, number of neurons/section, neuronal body area and neuronal nucleus area were evaluated. The protein deprivation prenatally and for 21 days postnatally leads to reduce body weights ( $40 \%$ of control weights) and an increase in the number of neurons/section (35\% more than control). Most neuron perikarya were within $400-600 \mu \mathrm{m}^{2}(53,7 \%)$ in protein-deprived animals and $600-900 \mu \mathrm{m}^{2}(48,2 \%)$ in the control group. Rows of neuronal bodies were separated by bundles of nerve and collagen fibers in both groups. Ganglionic neurons from both groups contained cytoplasmic Nissl's corpuscles and spherical nuclei with eccentric and large nucleoli. The elongated nuclei of the fibrocytes revealed the main axis oriented parallel to the bundles nerve fibers. By scanning electron microscopy, the structure of the ganglion from both groups was found to be similar.
\end{abstract}

\section{INTRODUCTION}

Protein energy deprivation (PED) severely alters the structure of organs and tissues in development. In the nervous system, PED affects mainly the central nervous system (CNS), where it leads to a reduction in encephalon mass [1], and a decrease in the number of neurons in the cerebral cortex and spinal cord [2]. Moreover, PED leads to reduced dendritic proliferation and delayed myelinization of the central nerve fibers [3, 4]. Studies of young, anorexic rats have shown that, in spite of an increased number of actively dividing CNS neurons, the total number of neurons is substantially reduced [5]. In the autonomic nervous system (ANS), the data are controversial regarding the estimated number of neurons in the myenteric plexus. PED has been shown to reduce the total number of neurons in esophagus and small intestine of rats [6-9]. However, the authors generally admit that PED determines a decrease in the size of neuronal bodies in the myenteric plexus of the esophagus, small and large intestines $[6,7,9,10]$. In the peripheral nervous system (PNS), PED delays the process of myelinization of the sciatic nerve [11] and increases axon density in the optic nerve [12]. Here, we examine the consequences of PED in the trigeminal ganglion, owing to its great importance for the sensitive process of orofacial innervations.

\section{MATERIALS AND METHODOLOGY}

Experiments were conducted according to regulations of the Biomedical Science Institute of the University of São Paulo (Ethical Principles in Animal Research adopted by Brazilian College of Animal Experimentation, COBEA).

*Address correspondence to this author at the VQM Autonomic Nervous System Laboratory, Anatomy Department, University of Sao Paulo, Brazil; Tel: 55 (11) 3091-7226; Fax: 55 (11) 3091 7366;

E-mail: ealibert@icb.usp.br

\section{EXPERIMENTAL GROUPS}

Young, male and female wistar rats were housed together for a period of seven to ten days. Pregnant females were separated into two groups. The nourished group (GI) was fed with the AIN-93G proteic ration (20\% casein) and the malnourished group (GII), with the AING-93 hypoproteic ration (5\% casein) [13]. Both groups were provided with water $a d$ libitum. Diets were unchanged until weaning of pups at 21 days of age, at which time pups were weighed, then euthanized by intraperitoneal injection of sodium pentobarbital (Hypnol 3\%, Fontovert) $(100 \mathrm{mg} / \mathrm{kg})$ and processed for light microscopy and scanning electron microscopy (SEM).

\section{Light Microscopy}

The encephalon was carefully removed from pups to expose the trigeminal ganglia on both sides of the base of the skull ( $\mathrm{n}=5$ for each group). Tissues were fixed in a $10 \%$ formalin for $48 \mathrm{~h}$. Ganglia were then removed, washed in distilled water for $18 \mathrm{~h}$, and dehydrated in an increasing alcohol series (50-100\%). After clearing in xylol, specimens were embedded in Paraplast (Merck). Five serial, $4 \mu \mathrm{m} \mathrm{sec-}$ tions were collected parallel to the ganglionic main axis and stained by hematoxylin-eosin (HE).

\section{Scanning Electron Microscopy}

Three-dimensional analysis by SEM was performed on two ganglia from each group. Specimens were dissected as previously described and immersed for $24 \mathrm{~h}$ at $4^{\circ} \mathrm{C}$ in a modified Karnovsky solution containing $2.5 \%$ glutaraldehyde and $2.0 \%$ paraformaldehyde in PBS (sodium phosphate buffer, $0.1 \mathrm{M}, \mathrm{pH}$ 7.4) [14]. After rinsing several times in PBS, specimens were digested by immersion in $5 \mathrm{M} \mathrm{KOH}$ solution at $60^{\circ} \mathrm{C}$ for 5 to $10 \mathrm{~min}$ and then for $24 \mathrm{~h}$ at $37^{\circ} \mathrm{C}$ in a type I collagenase solution (Sigma Aldrich) $(1 \mathrm{mg} / \mathrm{ml}$ in PBS) [15]. Digestion was stopped by immersion in a modified Karnowsky solution and samples were fixed with $1 \%$ osmium tetroxide $\left(\mathrm{OsO}_{4}\right)$ for $2 \mathrm{~h}$ at $4^{\circ} \mathrm{C}$. Ganglia were dehydrated in increasing concentrations of alcohol, dried with 
liquid $\mathrm{CO}_{2}$ in a critical point device (Balzers CPD-030), mounted and sprayed with gold in a Balzers SCD-040 ion sputter. Specimens were analyzed using a Cambridge Stereoscan 240 SEM.

\section{Morphometry}

Five sections from each trigeminal ganglion from GI and GII had their areas (in $\mathrm{mm}^{2}$ ) calculated [16] using a semiautomatic device for morphometry (KS300-Zeiss). The density of neuron cell bodies and the estimated total number of neurons were determined in each section examined under a binocular microscope at 400x magnification. Ten fields were chosen at random, and neuronal bodies were counted [17, 18]. The areas of 120 nerve cell bodies and nuclei for each animal from GI and GII were outlined [19] using the same semi-automatic device for morphometry.

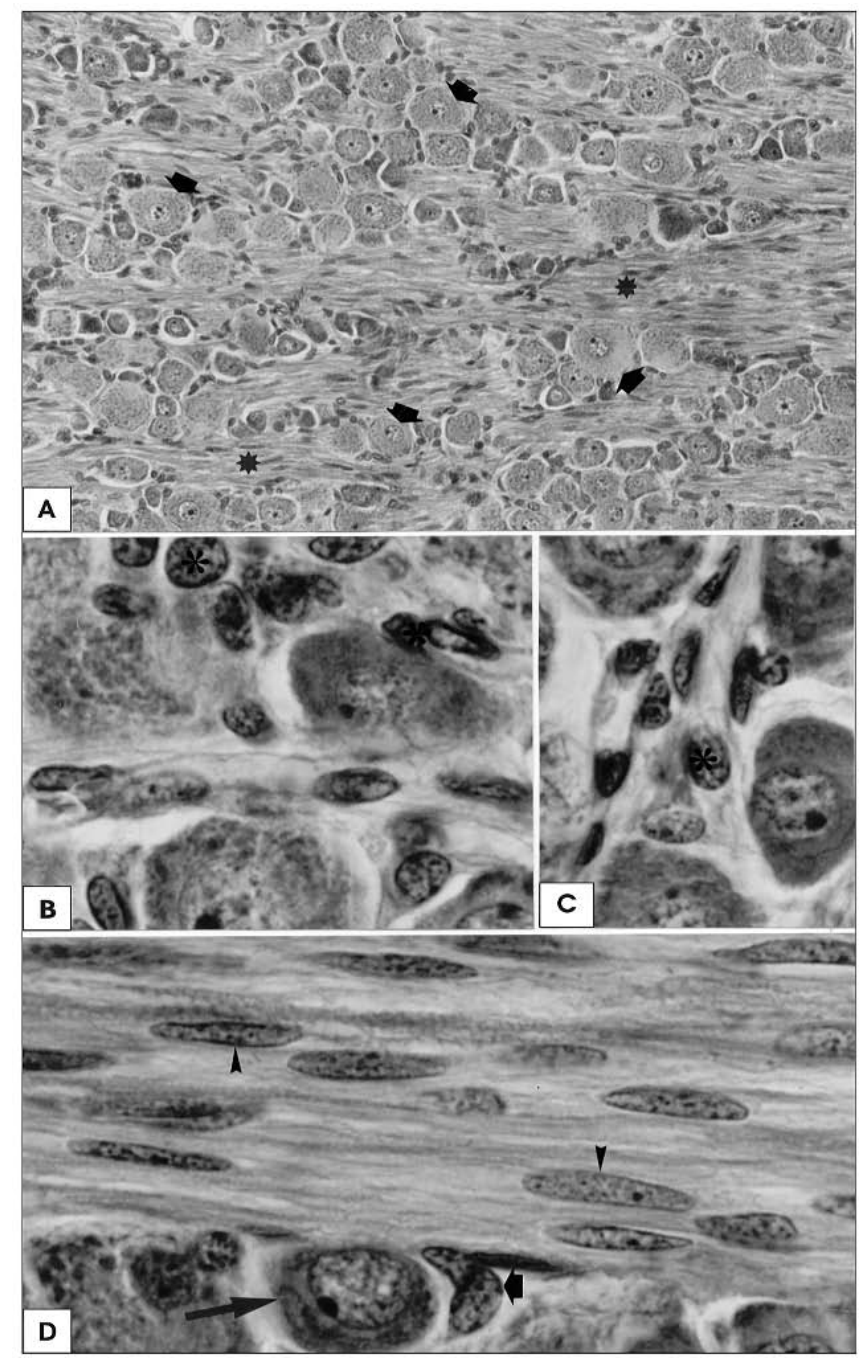

Fig. (1). Histological analysis of trigeminal ganglia from GI and GII. A) Gross organization of neurons of several sizes (arrows) grouped in rows oriented towards the ganglion's larger axis, separated by bundles of nervous and collagen fibers with the same orientation (*). 275x magnification. B, C) Satellite cells (*) around ganglion neuronal cell bodies, filling the space between them. 1.780x magnification. D) Cell body of ganglion neuron (larger arrow), satellite cells (smaller arrow) and elongated fibrocyte nucleus (arrowhead). 1.780x magnification.

\section{Statistical Analysis}

For all measured variables (body weight, ganglion area, neuronal density, number of neurons/section, cross sectional surface area of the neuronal body, neuronal nuclear area), a nonpaired Student's $t$ test was applied to compare the groups (GI, GII). The nonpaired Kolmogorov-Smirnov test was used to compare the frequency distribution of the values obtained for neuronal body and nuclear area [20]. The SPSSPC (SPSS-10, Chicago, IL) program was used for capturing, processing, and analyzing data. The null hypothesis was rejected when the $p$ value was 0.05 or less.

\section{RESULTS}

\section{Qualitative Analysis}

Several rows of neuronal bodies were observed in histological sections of the trigeminal ganglia of GI and GII rats. These parallel rows were oriented according to the main axis of the ganglia and were separated by bundles of nerve and collagen fibers of different thicknesses. Septa from the connective ganglionic capsule were not detected inside the ganglion wrapping groups of neurons (Fig. 1A). Nissl's corpuscles were observed in the cytoplasm of ganglionic neurons, which typically contained a clear and spherical nucleus with eccentric and large nucleolus. Satellite cells were also detected around the neuronal bodies. The elongated nuclei of the fibrocytes were identified and showed the main axis oriented parallel to the bundles nerve fibers (Fig. 1B-D).

Trigeminal ganglia from both groups (GI, GII) were similar by SEM analysis. That is, following partial removal of the collagenous component, similar overall structure was observed. In addition, bundles of nerve fibers were well compacted in both groups (Fig. 2A). At higher magnification, nerve fibers were oriented in different directions. These nerve fibers form a meshwork around the surface of the neuron cell bodies and comprised well-defined "loci" (Fig. 2B, C).

\section{Quantitative Analysis}

The mean of body weight was significantly reduced in GII $(19,0 \pm 0,9)$ when compared with GI $(51,8 \pm 7,7)$. GII animal body weights were approximately $40 \%$ of GI animals. The parameters ganglion cross sectional surface area, neuronal density, number of neurons/section, neuronal body surface area, neuronal nuclear surface area were measured in GI an GII weanlings, and mean values $( \pm$ SD) are listed in Table 1. With the exception of the ganglion $(p=0.056)$, all values were significantly affected by PED $(p \leq 0.05)$. Interestingly, PED appeared to cause an increase in the number of neurons/section and in neuronal density in GII animals; these values were approximately $35 \%$ and $40 \%$ higher, respectively, in GII than in GI animals.

The size of neuronal bodies, expressed as perikaryon area, ranged from $200-1400 \mu \mathrm{m}^{2}$ in GI and from 200-900 $\mu \mathrm{m}^{2}$ in GII. Most of neuron perikarya ranged from 600-900 $\mu \mathrm{m}^{2}(48.2 \%)$ in GI and $400-600 \mu \mathrm{m}^{2}(53.7 \%)$ in GII. Nuclear sizes ranged from $100-350 \mu \mathrm{m}^{2}$ in GI and from $50-250 \mu \mathrm{m}^{2}$ in GII. Most nuclear surface areas were within $200-250 \mu \mathrm{m}^{2}$ (32.7\%) for GI, and from $100-150 \mu \mathrm{m}^{2}(45.3 \%)$ for GII. 


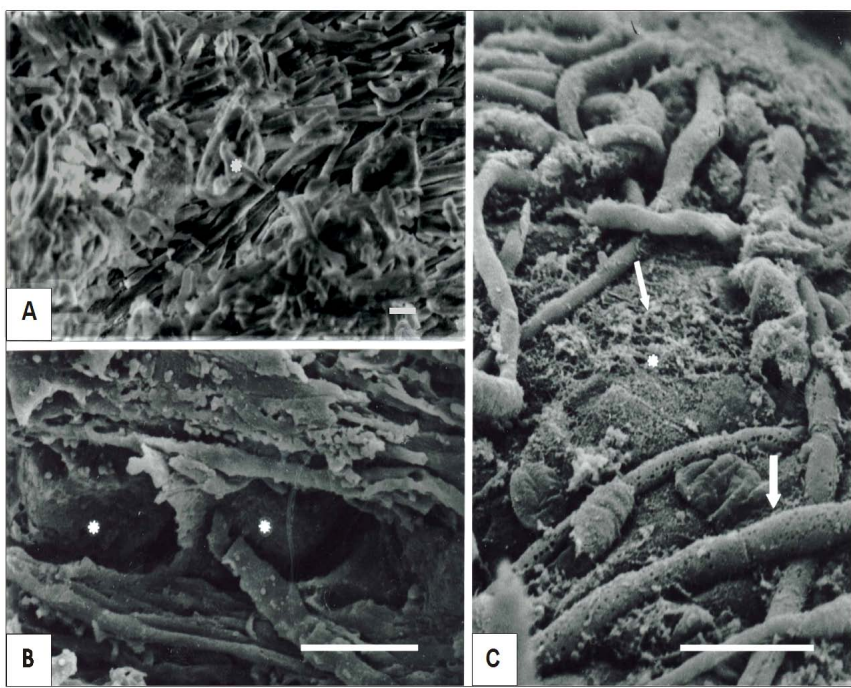

Fig. (2). Three-dimensional aspects of trigeminal ganglia from GI and GII. A) Fibers oriented in different directions compacted in bundles (*). B) Neuronal bodies (*) located within the "loci" delimited by the nervous fibers making up the ganglion. C) Remainders of collagen fibers partially digested by collagenase (small arrows), showing the neuronal body $(*)$. Nervous fibers oriented in different directions (large arrows) are also observed in contact with the neuronal body. SEM $($ Bar $=10 \mu \mathrm{m})$.

\section{DISCUSSION AND CONCLUSION}

A variety of different methods have been used to induce experimental malnutrition $[1,3,6,7,10]$. The method here employed [13] substantially reduced the body weight of animals compared with controls. Moreover it is consistent with the proposal that a significant decrease in body weight (60\% lower than nourished animals) is seen in rats submitted to pre-natal malnutrition [21]. Our observations of decreased neuronal body and nuclear area in undernourished rats are in accordance with studies of the myenteric plexus of large intestine of young undernourished rats where the myenteric neuron area decreased [10]. Also, these data are in agreement with studies demonstrating a reduction in the thickness of the myelin sheath in nerves of undernourished monkeys [22], late myelinization in the optic nerve of rats [23] and smaller endoneural areas and shorter internodal regions in the posterior tibial nerve of undernourished rats [24].

The observed increase in neuronal density of the trigeminal ganglion resulting from PED in our study is consistent with observations in the myenteric plexus of the small and large intestines. In these viscera, the number of neurons was higher in undernourished than in the control animals [7, 10], and in the optical nerve where axon density is increased in undernourished animals [12]. While the increase in total number of neurons here observed in the trigeminal ganglia of GII animals is similar to effects on myenteric neurons in the small intestine [7], the number of neurons was not different between the undernourished and normally fed animals in the large intestine [10].

Our research, however, does not agree with one study in which no significant difference in neuron size was observed in the rat dorsal root ganglion in malnourished rats [25]. The consequences of PED for the CNS are also controversial. While severe malnutrition causes nerve cell loss in some regions of the CNS (e.g., the dentate gyrus) [26], the cerebral cortex seems protected from neuronal loss [27]. Thus, among extrinsic factors that significantly decrease the number of neurons in different parts of the nervous system, such as Trypanosoma cruzi infection [28, 29] and aging [30], PED cannot be considered as deleterious. According to recent studies in the CNS [5], the proportional increase in proliferative cells observed in young homozygous mutant anorexic mice suggests a compensatory mechanism or a cell selfrenewal system that is altered with PED.

Interestingly, we found that morphological aspects of the trigeminal ganglion, by light microscopy and SEM were not substantially altered with PED. Rows of neurons, bundles of nerve and collagen fibers of different thicknesses, fibrous ganglionic capsule, as well as the neuronal "loci" were similar in both nourished and malnourished animals. Another structural characteristic of the trigeminal ganglion, the presence of satellite cells around neurons of different sizes, was observed in both groups. Comparatively, the trigeminal ganglion of the cat also contains neuron cell bodies arranged in rows or columns, where satellite cells are present in different densities [31]. The spherical nucleus with eccentric and large nucleolus observed in the trigeminal ganglia from both groups is observed in most neurons of ferret's trigeminal ganglion [32]. Perhaps other techniques, such as transmission electron microscopy, may reveal other alterations caused by PED. In fact, in esophageal myenteric neurons of malnourished rats, the membrane of the granular reticulum appeared thinner and ribosomes were arranged in clusters [9]. It is also possible that the effects of malnourishment on nervous structures depend not only upon the structure in question, but also on the period in which malnourishment occurred and the experimental model adopted. Thus, one may infer that nervous cells of the peripheral nervous system, regardless of the anatomical structure with which they are associated, will exhibit a similar response to malnourishment.

In conclusion our data suggest a model in which malnourishment triggers a delay in the development of PNS structures, because altered neuronal structure was not ob-

Table 1. Mean Values Related to Number of Neurons Estimated by Section, Neuronal Density, and Area of the Profiles of Trigeminal Ganglion / Cell Body / Nucleus

\begin{tabular}{|c|c|c|c|c|c|}
\hline & Ganglion Profile $\left(\mathbf{m m}^{2}\right)$ & Neuronal Body Profile $\left(\boldsymbol{\mu m}^{2}\right)$ & Neuronal Nucleus Profile $\left.(\boldsymbol{\mu m})^{2}\right)$ & Neurons/Section & Neurons/mm \\
\hline \hline GI & $3,7( \pm 0,3)$ & $707,0( \pm 59,3)$ & $226,0( \pm 21,2)$ & $1069( \pm 121)$ & $286( \pm 14)$ \\
\hline GII & $3,3( \pm 0,3)$ & $548,9( \pm 31,2)^{*}$ & $139,0( \pm 26,7)^{*}$ & $1604( \pm 218)^{*}$ & $484( \pm 45)^{*}$ \\
\hline
\end{tabular}

Values are presented as mean \pm standard deviation (SD), where GI is the nourished animals group or control group ( $\mathrm{n}=5$ ) and GII is the undernourished animals group ( $\mathrm{n}=5$ ).

*Significantly different from control $(\mathrm{p} \leq 0.05)$. 
served. Correlating this delay to a decrease in nervous conduction speed previously related $[23,33]$ will be the focus of future studies.

\section{ACKNOWLEDGEMENTS}

The authors thank Ms. Marta Maria S. Riguetti for technical assistance, Ms. Rosana Duarte Prisco for statistical analyses, and the Brazilian National Research Council (CNPq) for support to E.A. Liberti as career investigator.

\section{REFERENCES}

[1] Zamenhof S, Marthens VE, Margolis FL. DNA (cell number) and protein in neonatal brain: alteration by maternal dietary protein restriction. Science 1968; 160: 322-23.

[2] Cordeiro ME, Trejo M, Garcia E, Barros T, Rojas AM. Dendritic development in the neocortex of adult rats following a maintained pre natal and/or early post-natal life undernutrition. Early Hum Dev 1986; 14: 245-58.

[3] Shrader RE, Zeman FJ. Effect of maternal protein deprivation on morphological and enzymatic development of neonatal rat tissue. J Nutr 1969; 99: 401-12.

[4] Bedi KS. Nutrition effects on neuron numbers. Nutr Neurosci 2003; 6 : 141-52

[5] Kim MJ, Kim Y, Kim SA. Increases in cell proliferation and apoptosis in dentate gyrus of anorexia (anx/anx) mice. Neurosci Lett 2001; 302: 109-12.

[6] Santer RM, Conboy VB. Prenatal undernutrition permanently decreases enteric neuron number and sympathetic innervation of Auerbach's plexus in the rat. J Anat 1990; 168: 57-62.

[7] Brandão MCS, Angelis RC, Souza RR, Fróes LB, Liberti EA. Effects of pre- and postnatal energy deprivation on the myenteric plexus of the small intestine: a morphometric study in weanling rats. Nutr Res 2003; 23: 215-23.

[8] Gomes OA, Castelucci P, Vasconcellos Fontes RB, Liberti EA. Effects of pre-and postnatal protein deprivation and postnatal refeedng om myenteric neurons of the rat small intestine: A quantitative morphological study. Auton Neurosci 2006; 126-127: 277-84.

[9] Liberti EA, Fontes RB, Fuggi VM, Maifrino LB, Souza RR. Effects of combined pre- and post-natal protein deprivation on the myenteric plexus of the esophagus of weanling rats: A histochemical, quantitative and ultrastructural study. World J Gastroenterol 2007; 13(26): 3598-604

[10] Castelucci P, Souza RR, Angelis RC, Furness JB, Liberti EA. Effects of pre-postnatal protein deprivation and postnatal refeeding on myenteric neurons of the rat large intestine: a quantitative morphological study. Cell Tissue Res 2002; 310: 1-7.

[11] Hedley ETW, Meuser CS. The effect of undernutrition on myelination of the rat sciatic nerve. Lab Invest 1971; 24: 156-61.

[12] Wiggins RC, Fuller GN, Brizzee L, Bissel AC, Samorajski T. Mielination of the rat optic nerve during post natal undernourishment and recovery: a morphometric analysis. Brain Res 1984; 308: 263-72.

[13] Reeves PG, Nielsen H, Fahey GC. AIN-93 purifed diets for laboratory rodents final report of the americam instiute of nutrition ad hhoc writing committee on reformulation of the AIN 76A rodent diet. J Nutr 1993; 123: 39-51.

[14] Boldrini SC, Watanabe I, Konig Junior B, Liberti EA. Effects of pre- and postnatal protein deprivation on rat's hard palatine mu- cosae: a scanning electron microscopic study of the connective tissue papillae. Ann Anat 1998; 180: 445-48.

[15] Ushiki T, Ide C. A modiefied KOH-collagenase method applied to scanning electron microscopic observation of peripheral nerves. Arch Histol Cytol 1988; 51: 223-32.

[16] Crissman RS, Sodeman T, Denton AM, Warden RJ, Siciliano DA, Rhoades RW. Organization of primary afferent axons in the trigeminal sensory root and tract of the rat. J Comp Neurol 1996; 364 : 169-83.

[17] Lohr JB, Jeste DV. Locus ceruleus morphometry in aging and schizophrenia. Acta Psychiatr Scand 1988; 77: 689-97.

[18] Zimatkin SM, Kuznetsova VB, Strik ON. Spatial organization and morphometric characteristics of histaminergic neurons in the rat brain. Neurosci Behav Physiol 2006; 36: 467-71.

[19] Chazaud B, Sonnet C, Lafuste P. Satellite cells attract monocytes and use macrophages as a support to escape apoptosis and enhance muscle growth. J Cell Biol 2003; 163: 1133-43.

[20] Zar JH. Biostatistical Analysis. $2^{\text {nd }}$ ed. Prentice Hall: Englewood Cliffs 1984.

[21] Firmansyah A, Sunoto S, Suharyono S. Effect of malnutrition during different periods on the small intestine of the rat. Jpn J Exp Med 1989; 59: 1-7.

[22] Roy S, Singh N, Deo MG, Ramalingaswami V. Ultrastructure of skeletal muscle and peripheral nerve in experimental protein deficiency and its correlation with nerve conduction studies. J Neurol Sci 1972; 17: 399-409.

[23] Sima A, Sourander P. The effect of early undernutrition on the calibre spectrum of the rat optic nerve. A morphometric ultrastructural study. Acta Neuropathol 1974; 28: 151-60.

[24] Cornblath DR, Brown MJ. Influence of malnutrition is source of malnutrition on developing rat peripheral nerves. Exp Neurol 1988 99: 403-11.

[25] Sima A. Relation between the number of myelin lamellae and axon circumference in fibers of ventral and dorsal roots and optic nerve in normal, undernourished and rehabilitated rats. An ultrastructural morphometric study. Acta Physiol Scand 1974; 91: 1-38.

[26] Bedi KS. Effects of undernutrition during early life on granule cell numbers in the rat dentate gyrus. J Comp Neurol 1991; 311: 42533.

[27] Bedi KS. Undernutrition of rats during early life does not affect the total number of cortical neurons. J Comp Neurol 1994; 342: 52932 .

[28] Maifrino LB, Liberti EA, Watanabe IS, Souza RR. Morphometry and acethylcholinesterase activity of the myenteric neurons of the mouse colon in the chronic phase of experimental Trypanosoma cruzi infection. Am J Trop Med Hyg 1999; 60: 721-25.

[29] Rodrigues E, Liberti EA, Maifrino LBM, Souza RR. Cardiac denervation in mice infected with Trypanosoma cruzi. Ann Trop Med Parasitol 2002; 96: 125-30.

[30] Akamatsu FE, Souza RR, Liberti EA. Fall in the number of intracardiac neurons in aging rats. Mech Ageing Dev 1999; 109: 15361.

[31] Feher E, Szabó GY, Vayda J. Quantitative analysis of the cells of the cat's trigeminal ganglion. Acta Morphol Acad Scihung 1981; 29: 161-68.

[32] Palmer RJ, Holland GR. Nucleolar eccentricity in trigeminal ganglion neurons. J Anat 1988; 157: 163-68.

[33] Gregg JM, Dixon AD. Somatotopic organization of the trigeminal ganglion in the rat. Arch Oral Biol 1973; 18, 487-98. 